\title{
Predictors of Undergraduate Satisfaction With the Usage of University of Ilorin Web Portal
}

\author{
Ismail Olatunji Adeyemi, Pinheiro LP, Nigeria \\ (iD) https://orcid.org/0000-0001-9822-5950 \\ Abdulwahab Olanrewaju Issa, University of Ilorin, Nigeria
}

\begin{abstract}
This study examined undergraduate students' satisfaction with the university portal using information system success model (ISSM). This study adopted stratified random sampling technique to select a sample size of 394 from a total population of 40,609 undergraduate students of the University of Ilorin. Questionnaire was the instrument that was used in collecting data for the study. Out of all the 394 copies of questionnaire administered, only 362 copies were returned completely filled and validated for this study. Findings show that IT professionals are responsive to students' complaints, but they do not show enough empathy to them; the students found the portal useful, and they are satisfied with the overall use of the portal; and system quality, service quality, and information quality predict students' satisfaction of the portal. The study shows that information quality has the highest significant impact in determining the perceived usefulness of a web portal while system quality has the least significant impact in determining the perceived usefulness of a web portal.
\end{abstract}

\section{KEYWORDS}

Information Quality, Perceived Usefulness, Service Quality, Students' Satisfaction, System Quality

\section{INTRODUCTION}

The Web portal is a kind of Information System (IS) that offers a platform for effective information provision and organization of data. Basically, a portal is a subset of website that has been adopted by universities to aid the dissemination of information without physical contact. It is observed that there is a surge in the use of Web to source for information. Portals have been adopted in different establishments in order to effectively organize staff and customers/clients' data or information. Usually, a university portal serves as a gateway to access information as regards school activities, registration of courses, payment of school fees, check results, monitor admission process, check academic status, and book hostel accommodation.

Many universities have continued to maximize the nonstop advancement of Information Technology (IT). This underscores the assertion of Khwaldeh, Al-Hadid, Masa'deh, and Alrowwad (2017) that academic institutions provide Web portal services to facilitate educational information to their students in order to ensure effective management of issues and to satisfy students' needs. Tella, Bashorun, and Adu (2012) reported that the University of Ilorin Web portal contract agreement was signed with Simplex Automation System Ltd., Lagos, Nigeria in February 2008. However, the 
University of Ilorin students' portal was first implemented at the start of the new session of 2008/2009. The University of Ilorin students' portal has various features, and it is mandatory for every registered student of the University to have unique personal login details required to access their accounts.

According to Po-An Hsieh, Rai, Petter, and Zhang (2012), mandatory use of IS frustrates and compromises employees' activities and also negatively impacts customers. They, however, opined that in obligatory use of information system, user satisfaction is discretional and can elicit user's mental acceptance of the system and show the significant behavioral consequences. Rabaa'i (2009) observed that Information System Success Model (ISSM) is the most widely used model for IS success measure. This study examines students' satisfaction with the usage of the Web portal by the undergraduate students of University of Ilorin.

\section{STATEMENT OF PROBLEM}

Considering the amount of resources that is observed to have been invested on the development and maintenance of University of Ilorin Web portal, the need for gratification from the portal cannot be overemphasized. Therefore, it is essential that the portal is designed accordingly to achieve its optimum use and purpose and gives users' satisfaction. Tella and Bashorun(2012); and Tella and Adesakin (2013) examined undergraduates' use and satisfaction with the University of Ilorin portal but that was before new features were added to the portal. These new features were implemented between 2014-2015, and some of the features included bandwidth payment, bandwidth payment revalidation, print admission clearance, e-voting for the Student Union (SU) election, and check graduation status. The addition of the new features has made the portal become more robust and heavily used by the students. With all these, there has been no indication of students' satisfaction with the Web portal. This has left unanswered questions on the students' satisfaction with the portal. In view of this, this study adapts DeLone and McLean's ISSM constructs to measure the undergraduate students' satisfaction with University of Ilorin Web portal.

\section{Research Questions}

This study findings provide answers to the following questions:

1. What are the qualities of University of Ilorin Web portal from service, system and information attributes?

2. What is the perceived usefulness of University of Ilorin Web portal?

3. What is students' perceived satisfaction with University of Ilorin Web portal?

\section{Hypotheses}

The following null hypotheses are formulated and will be tested at 0.05 level of significance:

$\mathbf{H}_{\mathbf{0 1}}$ : There is no significant relationship between system quality of University of Ilorin Web portal and students' satisfaction.

$\mathbf{H}_{\mathbf{0}}$ : There is no significant relationship between service quality of University of Ilorin Web portal and students' satisfaction.

$\mathbf{H}_{03}$ : There is no significant relationship between information quality of University of Ilorin Web portal on students' satisfaction.

$\mathbf{H}_{\mathbf{0 4}}$ : System quality, service quality, information quality, and perceived usefulness would not significantly predict students' satisfaction with University of Ilorin Web portal. 


\section{REVIEW OF RELATED LITERATURE}

In a study of the factors affecting employees' satisfaction in Jordanian National Electricity Power Company, Aljarrah (2017) found that there is a positive significant relationship between system quality and users' satisfaction and that responsiveness of IT staff showed the highest effect on users' satisfaction. Furthermore, the authors found that information quality has a significant effect on user satisfaction. Mohamed, Hussein, and Hussein (2009) investigated users' satisfaction with Malaysia's electronic government systems and found that ease of use has the most significant impact on user satisfaction. Ajoye and Nwagwu (2014) found that ease of use has the highest significant effect on users' satisfaction while user interface has the least significant effect on users' satisfaction with the University of Ibadan postgraduate school portal. Moreover, it was found that IT self-efficacy has the most significant influence on user satisfaction of the university portal.

Chen (2012) found that a good interface has the highest correlation with users' satisfaction while ease of getting online assistance has the least correlation with users' satisfaction. Furthermore, it was found that the service quality leaves users with a poor experience and that there is a positive relationship between good interface for communication. Results further revealed that there is high correlation between accurate information and users' satisfaction while sufficiency of information has the least significant relationship with users' satisfaction. Shaltoni, Khraim, Abuhamad and Amer (2015) revealed that system qualityhas significant effect on users' satisfaction. Furthermore, it was found that information usefulness has more significant relationship to user satisfaction than information usability. Overall, the results show that educational service availability, system quality and information quality have a significant effect on students' satisfaction.

Herrera, Moraga, Caballero, and Calero (2012); and Mori (2013) found that that system quality has the most significant effect on user satisfaction compared to service and information qualities. However, Lai and Pires (2010) found that system quality does not have significant relationship with users' satisfaction. Protonotarios, Palavitsinis, and Manouselis (2013) found that most "Organic. Edunet" portal users found it easy to navigate within the portal. Furthermore, it was found that most of the users see the portal design as suitable and attractive, and it was shown that most users considered information provided on the portal as relevant only when it is easy to understand. The authors' findings revealed that the majority of the portal users were satisfied after using the portal.

Most studies have examined service quality from the dimension of characteristics of the IT support staff. Yet, the findings of these studies on the relationship between personnel characteristics and user satisfaction have produced mixed results. It was noted by Tandon and Singh (2018) that easiness and reliability of technology attract more customers and helps improve their loyalty. Tella and Mutula (2010) found that service quality is the least measures among all other factors used in the study to evaluate WebCT Course Content Management System. Similarly, Seyal and AbdRahman (2015) examined service quality of financial and accounting IS in Brunei and found that service quality does not have significant effect on users' satisfaction.

Oliha (2014) found that clarity of information has the most significant relationship with user satisfaction while provision of system help information was the least significant to user satisfaction. This gives a pointer that information clarity on portal can stimulate user satisfaction than provision of system help information. Halonen, Acton, Golden, and Conboy (2012) evaluated virtual learning environment and found that information quality has significant effect on user satisfaction. Zaied (2012) found that there is significant correlation between information quality and user satisfaction.

In mandatory use settings, users ordinarily have no judgment regarding either to accept or reject the system because it is compulsory on every user. Therefore, the behavior of "actual use" may not be a good measure of users' perceptions of the system. This is the scenario the students of University of Ilorin find themselves as the "use" of the University portal is mandated on registered students. In such event, Sharma, Shakya and Kharel (2014) argued that user satisfaction is a more fitting indication of 
users' overall fulfillment with the system. This motivates scholars like Chen(2012) to integrate TAM and user satisfaction to exploit the full benefits of both realm of research.

According to Ohk, Park, and Hong (2015), perceived usefulness is interpreted as the belief of high performance by using a certain system. They noted that perceived usefulness can be obtained when users find a system easy to use. Petter, DeLone and McLean (2008) found that there is strong support for the relationship between perceived usefulness and user satisfaction. Leclercq (2007), in a qualitative study, found that there is a relationship between perceived usefulness and user satisfaction. Abugabah, Sanzogni, and Alfarraj (2010) found that system support of the overall goal/desire has the most significant impact on user satisfaction while system support in the accomplishment of a task is the least significance related to user satisfaction. Kim and Lee (2010), and Chen (2012) found that perceived usefulness has positive significant impact on user satisfaction.

User satisfaction is multidimensional in the field of Information System (IS). This is buttressed by Brown, Venkatesh, and Goyal (2014) in that studies where user satisfaction is the primary focus, a wide variety of definitions coupled with the diversity of measures remain in use. Nevertheless, Vaezi, Mills, Chin, and Zafar (2016) concluded that researchers have continuously used and consented that user satisfaction is more accessible and flexible in application on a general scale, and an easily measured concept. Lee, Choi, and Jo (2009) analyzed students' satisfaction with campus portal services and found that the support service from IT professionals has the greatest influence on students's satisfaction. Nedeva and Zlatev (2013) found that user's experience and user interaction have the most significant relationship with students' satisfaction. Yoon, Nah, and Chin (2013) found that ease of use has the most significant impact on user satisfaction. Lai and Pires (2010) stressed that Web portal satisfaction is a requirement for intention-to-reuse the portal. Hence, it drives the student's behaviour towards the portal in mandatory use.

\section{CONCEPTUAL FRAMEWORK}

Figure 1.

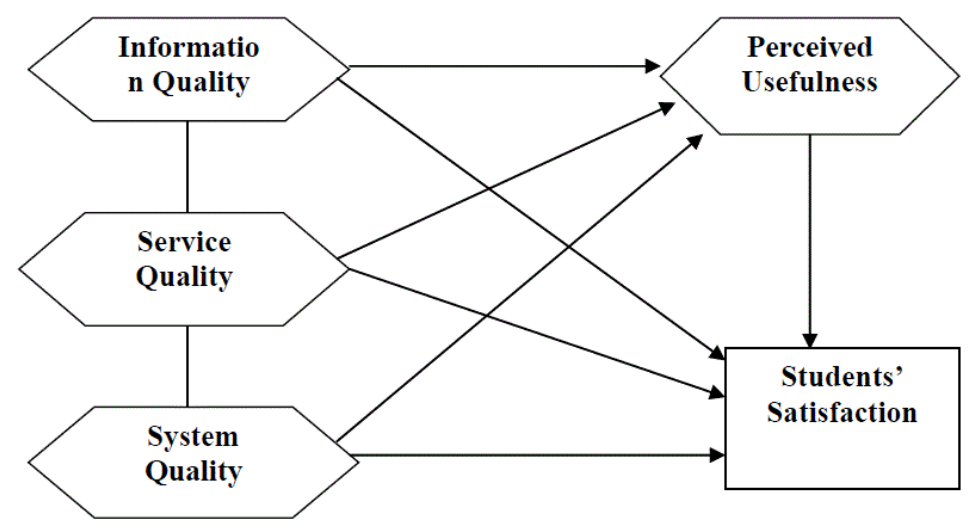

Source: Adeyemi and Issa (2020)

\section{METHODOLOGY}

This study adopts a positivist research paradigm of the ontological school of thought using the quantitative approach. Generally, a quantitative approach is used to assess objective theories and test 
the relationship between variables (Creswell, 2014). Also, the authors adopted a descriptive survey design. The total population for this study was 40,609 which is the total number of undergraduates according to the University of Ilorin Academic Planning Office (2016/2017). Using the Israel model (2003) at confidence level of $95 \%$ and $\mathrm{P}=0.5$ at precision of + or -5 , the sample size for this study is 394. The sampling technique is proportionate stratified sampling technique. Questionnaire was used for data collection. The Cronbach's alpha is 0.785 .

\section{RESULTS}

From the total of 394 copies of questionnaire administered on the respondents, only 362 were returned completely filled and validated for the study. Hence, the 362 copies of questionnaire stand as the unit of analysis for this study.

Table 1 illustrates the demographic information of the respondents. It is shown in the Table that there were slightly more male students in the study than their female counterparts. On the age distribution, it can be noted in the table that half of the respondents were below 20 years of age while the least of the respondents were 31 years of age and above. On the respondents' level of study, it is shown that the highest representation of the respondents were in 200 level while least number of the respondents were in 500 level. Moreover, the table shows that the highest number of the respondents were from the Faculty of Education while Faculties of Pharmaceutical Sciences and Medicines have the least number of respondents.

Table 2 shows that most of the respondents perceived the University of Ilorin Web portal as easy to use and most also agreed that the portal is easily accessible. The table also shows that most of the respondents found the Web portal prompt in response. However, it is shown in the table that most of the respondents do not found the user interface of University of Ilorin Web portal attractive. Moreover, it is shown in the table that most of the respondents agreed that the navigation functionality of the Web portal is simple and that a marginal number of the respondents disagreed that the University of Ilorin Web portal interface is attractive.

Table 3 shows that most of the respondents perceived the IT professionals in-charge of the University of Ilorin Web portal to be responsive to complaints and the Web portal as reliable. However, it is shown in the table that most of the respondents disagreed that IT professionals show empathy to students who lodge complaints at COMSIT and most of the respondents also disagreed that there is ease of getting online assistance on the Web portal. It is shown in Table 3 that most of the respondents agreed that IT professionals show a high level of technical competence in the process of discharging their duties and most of the respondents also agreed that IT professionals show positive attitude and degree of professionalism.

Table 4 shows that most of the respondents agreed that information on the Web portal is accurate and most of the respondents agreed the portal is filled with relevant information. It is shown in Table 4 that most of the respondents viewed that information on the Web portal is easy to read and that most of the respondents agreed that information on the portal is up-to-date. The Table 4 shows that most of the respondents see information provided on the University of Ilorin Web portal as concise and that most of them were of the view that information provided on the University of Ilorin Web portal is complete.

It can be seen in Table 5 that respondents see the task activities of the University of Ilorin Web portal as very important and that the University of Ilorin Web portal improves most of the respondents' learning experience. Also, it can be seen in Table 5 that more than half of the respondents believe the portal enhances effective completion of academic related activities. The table also shows that more than half of the respondents are comfortable with the use of the portal. Moreover, it is shown in the Table 5 that most of them found the University Web portal useful.

It is shown in Table 6 that most of the respondents were not really satisfied with the University of Ilorin Web portal design and that more than half of the respondents were either very satisfied or extremely satisfied with the overall usefulness of the University of Ilorin Web portal. It can be 
Table 1. Demographic information of respondent

\begin{tabular}{|c|c|c|}
\hline Variables & Frequency & Percentage (\%) \\
\hline \multicolumn{3}{|l|}{ Gender } \\
\hline Male & 192 & 53.0 \\
\hline Female & 170 & 47.0 \\
\hline Total & 362 & $100 \%$ \\
\hline \multicolumn{3}{|l|}{ Age } \\
\hline Below 20 years & 184 & 50.8 \\
\hline $21-25$ years & 92 & 25.4 \\
\hline 26-30 years & 73 & 20.2 \\
\hline 31 years and above & 13 & 3.6 \\
\hline Total & 362 & $100 \%$ \\
\hline \multicolumn{3}{|l|}{ Level of Study } \\
\hline 100 level & 84 & 23.2 \\
\hline 200 level & 136 & 37.6 \\
\hline 300 level & 70 & 19.3 \\
\hline 400 level & 48 & 13.3 \\
\hline 500 level & 24 & 6.6 \\
\hline Total & 362 & $100 \%$ \\
\hline \multicolumn{3}{|l|}{ Faculties } \\
\hline Agriculture & 37 & 10.2 \\
\hline Arts & 45 & 12.4 \\
\hline Basic Medical Sciences & 8 & 2.2 \\
\hline Clinical Sciences & 7 & 1.9 \\
\hline Communication and Information Sciences & 14 & 3.9 \\
\hline Education & 72 & 19.9 \\
\hline Engineering and Technology & 31 & 8.6 \\
\hline Environmental Sciences & 8 & 2.2 \\
\hline Law & 8 & 2.2 \\
\hline Life Sciences & 33 & 9.1 \\
\hline Management Sciences & 30 & 8.3 \\
\hline Pharmaceutical Sciences & 2 & 0.6 \\
\hline Physical Sciences & 33 & 9.1 \\
\hline Social Sciences & 32 & 8.8 \\
\hline Veterinary Medicines & 2 & 0.6 \\
\hline Total & 362 & $100 \%$ \\
\hline
\end{tabular}

Source: Author's Fieldwork (2019) 
Table 2. System qualities of University of Ilorin Web portal

\begin{tabular}{|c|c|c|c|c|c|c|c|c|c|c|}
\hline \multirow[t]{3}{*}{ Items } & \multicolumn{10}{|c|}{ Responses } \\
\hline & \multicolumn{2}{|c|}{$\begin{array}{c}\text { Strongly } \\
\text { Agreed }\end{array}$} & \multicolumn{2}{|c|}{ Agreed } & \multicolumn{2}{|c|}{ Neutral } & \multicolumn{2}{|c|}{ Disagreed } & \multicolumn{2}{|c|}{$\begin{array}{c}\text { Strongly } \\
\text { Disagreed }\end{array}$} \\
\hline & $\mathbf{N}$ & $\%$ & $\mathbf{N}$ & $\%$ & $\mathbf{N}$ & $\%$ & $\mathbf{N}$ & $\%$ & $\mathbf{N}$ & $\%$ \\
\hline Easy to Use & 113 & 31.2 & 108 & 29.8 & 47 & 13.0 & 63 & 17.4 & 31 & 8.6 \\
\hline Accessibility & 107 & 29.6 & 83 & 22.9 & 21 & 5.8 & 71 & 19.6 & 80 & 22.1 \\
\hline Portal Response & 126 & 34.8 & 92 & 25.4 & 26 & 7.2 & 51 & 14.1 & 67 & 18.5 \\
\hline Interactivity & 60 & 16.6 & 71 & 19.6 & 30 & 8.3 & 91 & 25.1 & 110 & 30.4 \\
\hline Navigation & 109 & 30.1 & 126 & 34.8 & 12 & 3.3 & 66 & 18.2 & 49 & 13.5 \\
\hline User Interface & 83 & 22.9 & 62 & 17.1 & 58 & 16.0 & 90 & 24.9 & 69 & 19.1 \\
\hline
\end{tabular}

Source: Author's Fieldwork (2019)

Table 3. Service qualities of University of llorin Web portal

\begin{tabular}{|c|c|c|c|c|c|c|c|c|c|c|}
\hline \multirow[t]{3}{*}{ Items } & \multicolumn{10}{|c|}{ Responses } \\
\hline & \multicolumn{2}{|c|}{$\begin{array}{c}\text { Strongly } \\
\text { Agreed }\end{array}$} & \multicolumn{2}{|c|}{ Agreed } & \multicolumn{2}{|c|}{ Neutral } & \multicolumn{2}{|c|}{ Disagreed } & \multicolumn{2}{|c|}{$\begin{array}{c}\text { Strongly } \\
\text { Disagreed }\end{array}$} \\
\hline & $\mathbf{N}$ & $\%$ & $\mathbf{N}$ & $\%$ & $\mathbf{N}$ & $\%$ & $\mathbf{N}$ & $\%$ & $\mathbf{N}$ & $\%$ \\
\hline Responsiveness & 93 & 25.7 & 101 & 27.9 & 38 & 10.5 & 75 & 20.7 & 55 & 15.2 \\
\hline Reliability & 89 & 24.6 & 96 & 26.5 & 43 & 11.9 & 73 & 20.2 & 61 & 16.8 \\
\hline Empathy & 42 & 11.6 & 57 & 15.7 & 30 & 8.3 & 102 & 28.2 & 131 & 36.2 \\
\hline Online Assistance & 25 & 6.9 & 31 & 8.6 & 28 & 7.7 & 128 & 35.4 & 150 & 41.4 \\
\hline Technical Competence & 135 & 37.3 & 114 & 31.5 & 26 & 7.2 & 56 & 15.4 & 31 & 8.6 \\
\hline Professionalism & 88 & 24.3 & 91 & 25.1 & 47 & 13.0 & 62 & 17.1 & 74 & 20.5 \\
\hline
\end{tabular}

Source: Author's Fieldwork (2019)

Table 4. Information qualities of University of Ilorin Web portal

\begin{tabular}{|c|c|c|c|c|c|c|c|c|c|c|}
\hline \multirow[t]{3}{*}{ Items } & \multicolumn{10}{|c|}{ Responses } \\
\hline & \multicolumn{2}{|c|}{$\begin{array}{c}\text { Strongly } \\
\text { Agreed }\end{array}$} & \multicolumn{2}{|c|}{ Agreed } & \multicolumn{2}{|c|}{ Neutral } & \multicolumn{2}{|c|}{ Disagreed } & \multicolumn{2}{|c|}{$\begin{array}{c}\text { Strongly } \\
\text { Disagreed }\end{array}$} \\
\hline & $\mathbf{N}$ & $\%$ & $\mathbf{N}$ & $\%$ & $\mathbf{N}$ & $\%$ & $\mathbf{N}$ & $\%$ & $\mathbf{N}$ & $\%$ \\
\hline Accuracy & 135 & 37.3 & 116 & 32.0 & 13 & 3.6 & 62 & 17.1 & 36 & 9.9 \\
\hline Relevant Information & 124 & 34.3 & 164 & 45.3 & 1 & 0.3 & 24 & 6.6 & 49 & 13.5 \\
\hline Easy to Read & 194 & 53.6 & 127 & 35.1 & 7 & 1.9 & 11 & 3.0 & 23 & 6.4 \\
\hline Up-to-date & 117 & 32.3 & 108 & 29.8 & 25 & 6.9 & 50 & 13.8 & 62 & 17.1 \\
\hline Conciseness & 98 & 27.1 & 112 & 30.9 & 12 & 3.3 & 46 & 12.7 & 94 & 26.0 \\
\hline Completeness & 122 & 33.7 & 109 & 30.1 & 32 & 8.9 & 58 & 16.0 & 41 & 11.3 \\
\hline
\end{tabular}

Source: Author's Fieldwork (2019) 
Table 5. Perceived usefulness of University of llorin Web portal

\begin{tabular}{|l|l|c|c|c|c|c|c|c|c|c|}
\hline \multirow{2}{*}{} & \multicolumn{9}{|c|}{ Items } & \multicolumn{10}{|c|}{$\begin{array}{c}\text { Strongly } \\
\text { Agreed }\end{array}$} & \multicolumn{2}{|c|}{ Agreed } & \multicolumn{2}{c|}{ Neutral } & \multicolumn{2}{c|}{ Disagreed } & \multicolumn{2}{c|}{$\begin{array}{c}\text { Strongly } \\
\text { Disagreed }\end{array}$} \\
\cline { 2 - 15 } & $\mathbf{N}$ & $\%$ & $\mathbf{N}$ & $\%$ & $\mathbf{N}$ & $\%$ & $\mathbf{N}$ & $\%$ & N & $\%$ \\
\hline Task activities & 141 & 38.9 & 128 & 35.4 & 10 & 2.8 & 46 & 12.7 & 37 & 10.2 \\
\hline Learning experience & 102 & 28.2 & 149 & 41.2 & 21 & 5.8 & 44 & 12.2 & 46 & 12.7 \\
\hline Academic activities & 98 & 27.1 & 100 & 27.6 & 26 & 7.2 & 51 & 14.1 & 87 & 24.0 \\
\hline Comfortability & 104 & 28.7 & 109 & 30.1 & 20 & 5.5 & 74 & 20.4 & 55 & 15.2 \\
\hline Useful & 127 & 35.1 & 135 & 37.3 & 15 & 4.1 & 49 & 13.5 & 36 & 10.0 \\
\hline
\end{tabular}

Source: Author's Fieldwork (2019)

observed in table that most of the respondents were either extremely satisfied or very satisfied with the information provision on the University of Ilorin Web portal. Moreover, Table 6 shows that less than half of the respondents were satisfied with the convenience of accessing the University of Ilorin Web portal and over half of the respondents were either very satisfied or extremely satisfied.

Table 6. Students' perceived satisfaction of University of Ilorin Web portal

\begin{tabular}{|c|c|c|c|c|c|c|c|c|c|c|}
\hline \multirow[t]{3}{*}{ Items } & \multicolumn{10}{|c|}{ Responses } \\
\hline & \multicolumn{2}{|c|}{$\begin{array}{c}\text { Extremely } \\
\text { Satisfied }\end{array}$} & \multicolumn{2}{|c|}{ Very Satisfied } & \multicolumn{2}{|c|}{$\begin{array}{c}\text { Moderately } \\
\text { Satisfied }\end{array}$} & \multicolumn{2}{|c|}{$\begin{array}{c}\text { Slightly } \\
\text { Satisfied }\end{array}$} & \multicolumn{2}{|c|}{ Not Satisfied } \\
\hline & $\mathbf{N}$ & $\%$ & $\mathbf{N}$ & $\%$ & $\mathbf{N}$ & $\%$ & $\mathbf{N}$ & $\%$ & $\mathbf{N}$ & $\%$ \\
\hline Portal design & 67 & 18.5 & 71 & 19.6 & 14 & 3.9 & 113 & 31.2 & 97 & 26.8 \\
\hline Usefulness & 79 & 21.8 & 105 & 29.0 & 68 & 18.8 & 58 & 16.0 & 52 & 14.4 \\
\hline Information provision & 126 & 34.8 & 99 & 27.3 & 48 & 13.3 & 65 & 18.0 & 24 & 6.6 \\
\hline Convenience & 72 & 20.0 & 91 & 25.1 & 62 & 17.1 & 74 & 20.4 & 63 & 17.4 \\
\hline Overall use & 86 & 23.8 & 115 & 31.8 & 78 & 21.5 & 66 & 18.2 & 17 & 4.7 \\
\hline
\end{tabular}

Source: Author's Fieldwork (2019)

\section{Test of Hypotheses}

$\mathbf{H}_{\mathbf{0 1}}$ : There is no significant relationship between system quality of Web portal and students' satisfaction.

It can be observed in Table 7 that $r$-cal, which denotes the Pearson correlation coefficient, is 0.990 . Also, the $p$-value is 0.000 , which is less than level of significance (0.05). This means that the null hypothesis is rejected. All these indicate that there is a significant relationship between system quality and students' satisfaction with the University of Ilorin Web portal. 
Table 7. Relationship between system quality and students' satisfaction

\begin{tabular}{|c|c|c|c|c|c|c|c|}
\hline Variables & Mean & SD & $\mathbf{N}$ & df & R-value & P-value & Remark \\
\hline System quality & 3.2274 & 1.41029 & \multirow[t]{2}{*}{362} & \multirow[t]{2}{*}{360} & \multirow[t]{2}{*}{$.990 * *$} & \multirow[t]{2}{*}{.000} & \multirow[t]{2}{*}{ Sig... } \\
\hline Students' satisfaction & 3.2536 & 1.30148 & & & & & \\
\hline
\end{tabular}

** Correlation is significant at 0.01 level (2-tailed)

Source: Author's Fieldwork (2019)

$\mathbf{H}_{\mathbf{0 2}}$ : There is no significant relationship between service quality of Web portal and students' satisfaction.

As it can be seen in Table 8, the $\mathrm{r}$-cal is 0.987 . Moreover, the $p=0.000$ which implies that the $p$-value is less than 0.05 level of significance. Hence, the null hypothesis, which says there is no significant relationship between service quality and students satisfaction is hereby rejected. In other words, there is significant relationship between service quality and students satisfaction.

$\mathbf{H}_{\mathbf{0 3}}$ : There is no significant relationship between information quality of Web portal on students' satisfaction.

Table 8. Relationship between service quality and students' satisfaction

\begin{tabular}{|c|c|c|c|c|c|c|c|}
\hline Variables & Mean & SD & $\mathbf{N}$ & df & R-value & P-value & Remark \\
\hline Service quality & 2.9650 & 1.30148 & \multirow[t]{2}{*}{362} & \multirow[t]{2}{*}{360} & \multirow[t]{2}{*}{$.987 * *$} & \multirow[t]{2}{*}{.000} & \multirow{2}{*}{ Sig... } \\
\hline Students' satisfaction & 3.2536 & 1.31643 & & & & & \\
\hline
\end{tabular}

${ }^{* *}$ Correlation is significant at 0.01 level (2-tailed)

Source: Author's Fieldwork (2019)

As it is shown in Table 9, ' $r$ ' value is 0.966 . The $p$-value is 0.000 , which is less than 0.05 level of significance. This means that the null hypothesis will be rejected. Consequently, this shows that there is a significant relationship between information quality and students' satisfaction.

$\mathbf{H}_{\mathbf{0 4}}$ : Information quality, service quality, and system quality will not significantly determine the perceived usefulness of Web portal.

Table 9. Relationship between information quality and students' satisfaction

\begin{tabular}{|l|l|l|l|l|l|l|l|}
\hline \multicolumn{1}{|c|}{ Variables } & \multicolumn{1}{|c|}{ Mean } & \multicolumn{1}{c|}{ SD } & \multicolumn{1}{c|}{ N } & \multicolumn{1}{c|}{ df } & \multicolumn{1}{c|}{ R-value } & \multicolumn{1}{c|}{ P-value } & \multicolumn{1}{c|}{ Remark } \\
\cline { 1 - 5 } Information quality & 3.6699 & 1.31494 & 362 & 360 & $.966 * *$ & .000 & Sig... \\
\cline { 1 - 4 } Students' satisfaction & 3.2536 & 1.30148 & & & & & \\
\hline
\end{tabular}

** Correlation is significant at 0.01 level (2-tailed)

Source: Author's Fieldwork (2019) 
In Table 10, the $\mathrm{R}$ value represents the simple correlation and is 0.994 , which indicates a high degree of correlation. It can also be seen that $98.8 \%$ of the total variance in dependent variable (perceived usefulness) can been explained by the independent variables (information quality, system quality and service quality) with $0.988 \mathrm{R}$-square. The adjusted R-square indicates the goodness-of-fit for the model, which is 0.988 . The standard error of the estimate shows that the average distance of the data points from the fitted line is about $0.2 \%(0.14748)$ body fat, which is good as it indicates that the observations are closer to the fitted line.

Table 10. Model Summary

\begin{tabular}{|l|l|l|l|l|}
\hline Model & \multicolumn{1}{|c|}{$\mathbf{R}$} & \multicolumn{1}{|c|}{ R Square } & \multicolumn{1}{c|}{ Adjusted R Square } & Std. Error of the Estimate \\
\hline 1 & $.994^{\mathrm{a}}$ & .988 & .988 & .14748 \\
\hline \multicolumn{2}{|l}{ a. Predictors: (Constant), InfoQual, SysQual, ServQual } \\
\hline
\end{tabular}

Source: Author's Fieldwork (2019)

Table 11 shows that the $\mathrm{f}$-value is greater than one and it is statistically significant. The $p$-value is 0.000 , which is lower than the 0.05 level of significance. Hence, the null hypothesis will be rejected and can conclude that the model provides a better fit than the intercept-only model. This means that information quality, service quality, and system quality will significantly determine the perceived usefulness of Web portal.

\section{Table 11. ANOVA}

\begin{tabular}{|l|l|l|l|l|l|c|}
\hline \multicolumn{2}{|c|}{ Model } & \multicolumn{1}{|c|}{ Sum of Squares } & \multicolumn{1}{c|}{ Df } & \multicolumn{1}{c|}{ Mean Square } & \multicolumn{1}{c|}{ F } & Sig. \\
\hline \multirow{3}{*}{1} & Regression & 667.708 & 3 & 222.569 & $1.023 \mathrm{E} 4$ & $.000^{\mathrm{a}}$ \\
\cline { 2 - 7 } & Residual & 7.787 & 358 & .022 & & \\
\cline { 2 - 7 } & Total & 675.495 & 361 & & & \\
\hline \multicolumn{2}{|l|}{ a. Predictors: (Constant), IQ, SysQua, ServQua } & & & \\
\hline \multicolumn{2}{|l|}{ b. Dependent Variable: Perceived Usefulness }
\end{tabular}

Source: Author's Fieldwork (2019)

In Table 12, t-stat represents regression coefficient divided by its standard error and it shows that information quality has a huge statistical distance away from zero, which translates to a very statistically significant regression coefficient with a $p$-value of 0.000 . Also, with $p$-value of 0.000 for service quality, it shows that it is lower than the common alpha level of 0.05 . Hence, it means that service quality has statistically significant effect on perceived usefulness. However, with $p$-value of 0.508 for service quality, it reflects that it is higher than the common alpha level of 0.05 . Thus, it means that system quality does not significantly determine perceived usefulness.

$\mathbf{H}_{\mathbf{0}}$ : System quality, service quality, information quality, and perceived usefulness will not significantly predict students' satisfaction with University of Ilorin Web portal.

Table 13 shows that the $\mathrm{R}$ value is 0.993 , which represents the simple correlation. This means there is a high degree of correlation. Also, with $\mathrm{R}$ Square of $0.986,98.6 \%$ of the total variance in 


\begin{tabular}{|c|c|c|c|c|c|c|}
\hline \multicolumn{2}{|r|}{ Model } & \multicolumn{2}{|c|}{ Unstandardized Coefficients } & \multirow{2}{*}{$\begin{array}{c}\begin{array}{c}\text { Standardized } \\
\text { Coefficients }\end{array} \\
\text { Beta }\end{array}$} & \multirow[t]{2}{*}{$\mathbf{T}$} & \multirow[t]{2}{*}{ Sig. } \\
\hline & & B & Std. Error & & & \\
\hline \multirow[t]{4}{*}{1} & (Constant) & -0.176 & .027 & & -6.6584 & .000 \\
\hline & System Quality & -.030 & .045 & -.031 & -.663 & .508 \\
\hline & Service Quality & .179 & .037 & .172 & 0.4796 & .000 \\
\hline & Information Quality & .895 & .024 & .860 & 36.605 & .000 \\
\hline \multicolumn{3}{|c|}{ a. Dependent Variable: PerUse } & & & & \\
\hline
\end{tabular}

Source: Author's Fieldwork (2019)

Table 13. Model Summary

\begin{tabular}{|l|l|l|l|l|}
\hline Model & \multicolumn{1}{|c|}{ R } & \multicolumn{1}{|c|}{ R Square } & \multicolumn{1}{c|}{ Adjusted R Square } & Std. Error of the Estimate \\
\hline 1 & $.993^{\mathrm{a}}$ & .986 & .986 & .15420 \\
\hline
\end{tabular}

Source: Author's Fieldwork (2019)

dependent variable (students' satisfaction) can be explained by the independent variables (system quality, service quality, information quality and perceived usefulness). With standard error of the estimate of 0.15420 that means the average distance of the data points from the fitted line is about $0.2 \%$, which reflects that the observations are closer to the fitted line.

In Table 14, f-value is 6.340E3, which shows that the null hypothesis is false as the value is greater than 1 . The $p$-value is 0.00 , which is lower than the 0.05 level of significance. Hence, the null hypothesis will be rejected and that means system quality, service quality, information quality and perceived usefulness will significantly predict students' satisfaction with the University of Ilorin Web portal.

\section{Table 14. ANOVA}

\begin{tabular}{|l|l|l|l|l|l|c|}
\hline \multicolumn{2}{|c|}{ Model } & \multicolumn{1}{|c|}{ Sum of Squares } & \multicolumn{1}{c|}{ df } & \multicolumn{1}{c|}{ Mean Square } & \multicolumn{1}{c|}{ F } & Sig. \\
\hline \multirow{3}{*}{1} & Regression & 602.992 & 4 & 150.748 & $6.340 \mathrm{E} 3$ & $.000^{\mathrm{a}}$ \\
\cline { 2 - 7 } & Residual & 8.488 & 357 & .024 & & \\
\hline & Total & 611.480 & 361 & & & \\
\hline \multicolumn{2}{|l|}{ a. Predictors: (Constant), SysQ, SeQ, IQ, PerUse } & & & \\
\hline \multicolumn{2}{|l}{ b. Dependent Variable: Students' Satisfaction }
\end{tabular}

Source: Author's Fieldwork (2019)

Table 15 shows that system quality and service quality show huge statistical distance away from zero, which indicates that they both have statistically significant regression coefficient with a $p$-value of 0.000 . Also, the information quality shows minor statistical distance away from zero with 2.371 and $p$-value of 0.018 , which shows that it is statistically significant. However, perceived usefulness is 
closer to closer to zero with p-value of 0.355 , which is greater than the common alpha level of 0.05 . Hence, perceived usefulness is not statistically significant to students' satisfaction in mandatory use of University of Ilorin Web portal.

Table 15. Coefficients ${ }^{\mathrm{a}}$

\begin{tabular}{|c|c|c|c|c|c|c|}
\hline \multicolumn{2}{|r|}{ Model } & \multicolumn{2}{|c|}{ Unstandardized Coefficients } & \multirow{2}{*}{$\begin{array}{c}\begin{array}{c}\text { Standardized } \\
\text { Coefficients }\end{array} \\
\text { Beta }\end{array}$} & \multirow[t]{2}{*}{$\mathbf{T}$} & \multirow[t]{2}{*}{ Sig. } \\
\hline & & B & Std. Error & & & \\
\hline \multirow[t]{5}{*}{1} & (Constant) & .183 & .030 & & 6.203 & .000 \\
\hline & System Quality & .327 & .047 & .354 & 6.920 & .000 \\
\hline & Service Quality & .454 & .040 & .460 & 11.297 & .000 \\
\hline & Information Quality & .132 & .056 & .134 & 2.379 & .018 \\
\hline & Perceived Usefulness & .051 & .055 & .054 & 0.926 & .355 \\
\hline & ent Variable: Satisfac & & & & & \\
\hline
\end{tabular}

Source: Author's Fieldwork (2019)

\section{DISCUSSION OF FINDINGS}

This study revealed that the University of Ilorin Web portal is easy to use. This buttresses the findings of Protonotarios, Palavitsinis, and Manouselis (2013) that most portal users do not face difficulties in learning how to operate the Web portal, which shows that it was easy to use. Furthermore, it was found in the study by Ajoye and Nwagwu (2014) that ease of use has the highest significant effect on users' satisfaction. Also, the study found that there is ease of accessibility with the University of Ilorin Web portal. This supports the findings of Aljarrah (2017) that there is ease of accessibility in the Web portal. Additionally, it was found that the University of Ilorin Web portal is prompt in response and the navigation functionality of the portal is simple. It was found in Lai and Pires (2010) that navigation does not have significant effect on user satisfaction. However, it was revealed that the user interface of University of Ilorin Web portal is not attractive enough to the students. This is somewhat related to the findings of Ajoye and Nwagwu (2014) that user interface has the least significant effect on user satisfaction. The study found that there is significant relationship between system quality and students' satisfaction. This underpins the findings of Lai and Pires (2010) that there is significant relationship between system quality and users' satisfaction.

Moreover, it was found that most of the students perceived the IT professionals in-charge of the University of Ilorin Web portal to be responsive to complaints and show empathy to the students when they lodge complaints. This corroborates the findings of $\mathrm{Wu}$, Tao, and $\mathrm{Li}$ (2012) that responsiveness and efficiency are one of the factors affecting service quality of a blog website. Moreover, the study revealed that the IT professionals in charge of the University of Ilorin Web portal demonstrate high level of competence whenever they attend to complaints from students. However, it was revealed that there is no ease in getting online assistance on the University of Ilorin Web portal. It was also found that the Web portal is reliable. In same vein, this is supported by Tandon and Singh (2018) findings that reliability of technology is what improve users' loyalty. Also, the study revealed that the IT professionals show positive attitude and degree of professionalism. Results show that there is significant relationship between service quality and students' satisfaction. This negates the findings of Seyal and AbdRahman (2015) that service quality does not have significant relationship with users' satisfaction. 
Results revealed that information on the University of Ilorin portal is accurate and filled with relevant information. This supports the findings of Shaltoni, Khraim, Abuhamad, and Amer (2015) that information should normally be accurate and relevant so as to help facilitate innovative services to the students. The study also found that information on the University of Ilorin Web portal is easy to read and up-to-date. Chen (2012) found that up-to-date information on a Web portal can help improve users' satisfaction of the portal. Moreover, the study revealed that information provided on the University of Ilorin Web portal is concise and complete. This supports the findings of Oliha (2014) that clarity of information has the most significant relationship with user satisfaction. Moreover, this will help reduce verbose information, which may lead to disinterestedness.Also, it was revealed that there is significant relationship between information quality and students' satisfaction.

Additionally, it was revealed that the task activities on the University of Ilorin portal are very important. Moreover, it was found that the Web portal improves students' learning experience and enhances effective completion of academic related activities. Abugabah, Sanzogni, and Alfarraj (2010) observed that facilitating the achievement of overall goal is the hallmark of perceived usefulness of an information system by the end-user. Hence, this means that the University of Ilorin portal is useful. Furthermore, it was found that students are comfortable with the use of the portal. Overall, the study found that the students found the portal to be useful. This finding oppose that of Oliha (2014) that most University of Benin's portal users were not pleased regarding the usefulness.

Lastly, it was found that less than half of the respondents were satisfied with the convenience of accessing the University of Ilorin portal. This corroborates the finding of Herrera, Moraga, Caballero, and Calero (2012) that most users are satisfied with the system quality of Web portal. Furthermore, it was revealed that most of the respondents were either extremely satisfied or very satisfied with the information provision on the portal.Moreover, it was found that more than half of the respondents were either very satisfied or extremely satisfied with the overall usefulness of the portal. It was revealed that most of the respondents were not really satisfied with the Web portal design. The results also revealed that system quality, service quality and information quality can significantly predict students' satisfaction with University of Ilorin Web portal. However, it was revealed that perceived usefulness is not statistically significant in predicting students' satisfaction of University of Ilorin Web portal.

\section{CONCLUSION}

Based on the findings, this study concludes that the University of Ilorin Web portal has been highly satisfactory to the students and the quality of information they get from the portal has been the most significant predictor of their satisfaction. The study also established that though factors such as ease of use, accessibility, user interface and user interactive have significant effect on students' satisfaction; these factors do not determine the perceived usefulness of a Web portal. It was also concluded that, in mandatory use, students are not really concerned with the perceived usefulness of the Web portal before they derive satisfaction from it. However, to derive satisfaction, students are highly concerned with the information qualities as provided on the Web portal. Based on the findings and conclusion, the following recommendations are proffered:

1. The user interface of the portal should be upgraded with feature such as live chat widget so as to make the system quality more interactive to the students. This will also be of help to students who seek online assistance.

2. IT professionals at the Computer Services and Information Technology (COMSIT) centre should be advised to show more empathy with students who lodge complaints at the Centre.

3. Moreover, a customer support/service portal should be designed, which will be administered by individuals with polished service quality.

4. Qualitative information provision should be essential in the maintanenance of the portal.

5. The academic/class usefulness of the portal should be improved. 


\section{CONTRIBUTIONS TO KNOWLEDGE}

The findings of this study contributed to knowledge by showing that, in mandatory use of a university portal, perceived usefulness of a Web portal does not predict students' satisfaction. Moreover, it has contributed that information quality is the highest determinants in predicting students' satisfaction in mandatory use of a Web portal.Furthermore, the study added to literature that service quality has the most significant effect in predicting students' satisfaction of a Web portal while perceived usefulness has the least significant effect and that the perceived usefulness of the Web portal is not enough to predict students' satisfaction in mandatory use of the Web portal. 


\section{REFERENCES}

Abugabah, A., Sanzogni, L., \& Alfarraj, O. (2010). Evaluating the impact of information systems on end-user satisfaction: A proposed model. International Journal of Advanced Computer Science and Applications, 1(1), 22-29. doi:10.14569/IJACSA.2010.010104

Adeyemi, I. O., \& Issa, A. O. (2020). Integration of information system success model and technology acceptance model: Proposing students' satisfaction with university web portal model. Record and Library Journal, 6(1), 69-79. doi:10.20473/rlj.V6-I1.2020.69-79

Ajoye, M. B., \& Nwagwu, W. E. (2014). Information systems users' satisfaction: A survey of the postgraduate school portal, University of Ibadan, Nigeria. Library Philosophy and Practice (e-journal), paper 1192. Retrieved from https://digitalcommons.unl.edu/libphilpract/1192

Aljarrah, M. (2017). Factors affecting employees' portal satisfaction in Jordanian National Electric Power Company. European Journal of Business and Management, 19(18), 69-77.

Brown, S. A., Venkatesh, V., \& Goyal, S. (2014). Expectation confirmation in information systemsresearch: A test of six competing models. Management Information Systems Quarterly, 38(3), 729-729. doi:10.25300/ MISQ/2014/38.3.05

Chen, Y. H. (2012). Undergraduates' perceptions and use of the university libraries web portal: Can information literacy instruction make a difference? Information Systems Research, 5(4), 378-399.

Creswell, J. W. (2014). Research Design: Qualitative, Quantitative and Mixed Methods Approaches (4th ed.). SAGE Publications.

Halonen, R., Acton, T., Golden, W., \& Conboy, K. (2012). DeLone and McLean success model as a descriptive tool in evaluating a virtual learning environment. Computers in Human Behavior, 15(3), 1105-1123.

Herrera, M., Moraga, M. A., Caballero, I. \& Calero, C. (2012). Quality in use model for Web portals. Alarcos Research Group, Department of Technologies and Information System, University of Castilla - La Mancha.

Khwaldeh, S. M., Al-Hadid, I., Masa'deh, R., \& Alrowwad, A. (2017). The association between e-services web portals information quality and ICT competence in the Jordan universities. Asian Social Science, 13(3), 156-169. doi:10.5539/ass.v13n3p156

Kim, Y. \& Lee, H. S. (2010). Quality, perceived usefulness, user satisfaction, and intention to use: An empirical study of ubiquitous personal robot service. Asian Social Science, 10(11), 1-16.

Lai, C. S. A., \& Pires, G. (2010). Testing of a model evaluating e-government portal acceptance and satisfaction. The Electronic Journal Information Systems Evaluation, 13(1), 35-46.

Leclercq, A. (2007). The perceptual evaluation of information systemsusing the construct of user satisfaction: Case study of a large Frenchgroup. The Data Base for Advances in Information Systems, 38(2), 27-60. doi:10.1145/1240616.1240621

Lee, H. S., Choi, Y. H., \& Jo, N. O. (2009). Determinants affecting users' satisfaction with campusportal services in Korea. Journal of Internet Banking and Commerce, 14(1), 1-18.

Mohamed, N., Hussein, H., \& Hussein, R. (2009). Measuring users' satisfaction with Malaysia's electronic government systems. Electronic. Journal of E-Government, 7(3), 283-294.

Mori, K. (2013). NEC group paves the way for smart devices. NEC Technical Journal, 7(3), 12-15.

Nedeva, V., \& Zlatev, Z. (2013). Quality of the services provided by a university Web portal. Applied Researches in Technics, Technologies, and Education, 1(3), 173-180.

Ohk, K., Park, S. B., \& Hong, J. W. (2015). The influence of perceived usefulness, perceived ease of use, interactivity, and ease of navigation on satisfaction in mobile application. Advanced Science and Technology Letters, 84, 88-92. doi:10.14257/astl.2015.84.18

Oliha, F. O. (2014). Web portal usability among Nigerian university students: A case study of University of Benin, Nigeria. Nigerian Journal of Technology, 33(2), 199-206. doi:10.4314/njt.v33i2.9 
Petter, S., DeLone, W., \& McLean, E. (2008). Measuring information system success: Models, dimensions, measures, and interrelationship. European Journal of Information Systems, 17(3), 236-263. doi:10.1057/ ejis. 2008.15

Po-An Hsieh, J. J., Rai, A., Petter, S., \& Zhang, T. (2012). Impact of user satisfaction with mandated CRM use on employee service quality. Management Information Systems Quarterly, 36(4), 1065-1080. doi:10.2307/41703498

Protonotarios, V. E., Palavitsinis, N., \& Manouselis, N. (2013). Organic.edunet Web portal: Users' satisfaction analysis. Greek Research \& Technology Network.

Rabaa'i, A. A. (2009). Assessing information systems success models: empirical comparison (Research-inProgress). In Proceedings of the 20th Australasian Conference on Information Systems. Monash University.

Seyal, A. H., \& AbdRahman, N. (2015). A preliminary investigation of measuring user satisfaction and success on financial and accounting information science: Bruneian perspective. International Journal of Business and Management Review, 3(2), 1-22.

Shaltoni, A. M., Khraim, H., Abuhamad, A., \& Amer, M. (2015). Exploringstudents' satisfaction with universities' portals in developing countries. International Journal of Information and Learning Technology, 32(2), 82-93. doi:10.1108/IJILT-12-2012-0042

Sharma, G., Shakya, S., \& Kharel, P. (2014). Technology acceptance perspectives on user satisfaction and trust of e-government adoption. Journal of Applied Sciences, 14(9), 860-872. doi:10.3923/jas.2014.860.872

Tandon, M., \& Singh, A. (2018). Basic minor and major ramifications of service quality in retail banking. International Journal of Advance Research, Ideas and Innovation in Technology, 4(1), 233-237.

Tella, A., \& Adesakin, M. A. (2013). An assessment of use and currency of information on the undergraduate students' web portal at the University of Ilorin. The Information Manager, 13(1\&2), 48-58.

Tella, A., \& Bashorun, M. T. (2012). Undergraduate students' satisfaction with web portal. International Journal of Web Portals, 4(4), 1-15.

Tella, A., Bashorun, M. T., \& Adu, E. O. (2012). Impact of web portals on e-learning. Journal of Science and Technology, 3(7), 766-773.

Tella, A., \& Mutula, S. (2010). A proposed model for evaluating the success of WebCT course content management system. Computers in Human Behavior, 26(6), 1795-1805. doi:10.1016/j.chb.2010.07.007

Vaezi, R., Mills, A., Chin, W., \& Zafar, H. (2016). User satisfaction research in information systems: Historical roots and approaches. Communications of the Association for Information Systems, 38(27), 1-33.

Wu, Y. L., Tao, Y. H., \& Li, C. P. (2012). Development and validation of a scale to measure blog service quality. Journal of Human-Computer Studies, 2(4), 23-35.

Yoon, H., Nah, J., \& Chin, W. (2013). Measuring end users' satisfaction with hospital's mobile health system in Korea. International Journal of $u$ - and e-Service. Science, and Technology, 6(6), 21-30.

Zaied, A. N. (2012). An integrated success model for evaluating information system in public sectors. Journalof Emerging Trends in Computing and Information Sciences, 3(6), 814-825. 
Ismail Adeyemi is currently a Librarian at Pinheiro LP, Ilupeju, Lagos State. He holds a Bachelor degree of Library and Information Science and currently pursuing his Master degree in same discipline, from the Department of Library and Information Science, University of Ilorin. He was the General Secretary of National Association of Library and Information Science Students (University of Ilorin) in the 2012/2013 session. He interned at Kwara State Public Library and was part of the team that developed Roemichs International School Library in Ilorin, Nigeria. He has worked with Olusegun Obasanjo Presidential Library (Library Officer/Admin Assistant) and Lamp Bearer Islamic School (School Librarian).

Abdulwahab Olanrewaju Issa holds DLS (1987), BLS (1991), and MLS (1996) Degrees from the Ahmadu Bello University, Zaria, and a PhD from the University of Ibadan (2007). He has taught in different library schools in Nigeria since 1992, including the Ahmadu Bello University, Zaria; the Federal Polytechnic, Offa; Tai Solarin University of Education, Ijebu-Ode; Kwara State University, Malete, and is currently, a Professor of Library and Information Science at the University of Ilorin. He is at present the University Librarian, University of Ilorin, Library. He has also been an ex-Head of a LIS Department, ex-Director, Centre for Continuing Education and ex-Chief Lecturer, Federal Polytechnic, Offa, Kwara State, Nigeria, Issa was once Vice-Chairman and Chairman, Nigerian Library Association, Kwara State Chapter, and thus, a National Council member of NLA. 